УДК 655.026, 655.3.066.364

( Т. Ю. Киричок, к.Т.н, доцент, А. М. Мережинська, аспірантка, О. В. Гуща, магістрантка, НТУУ «КПІ», Київ, Україна

\title{
ТАКТИЛЬНА ДИСКРИМІНАЦІЯ ПАПЕРОВИХ БАНКНОТ ПІСЛЯ ЛАКУВАННЯ ВОДОДИСПЕРСНИМ ЛАКОМ
}

У дослідженні за допомогою методики, що базується на 3-альтернативній процедурі відбору “одного 3 .... було проведено тактильну дискримінацію поверхні банкнот, лакованих вододисперсним лаком із додаванням нанорозмірних часток срібла у якості бактерицидного агенту.

Ключові слова: банкноти, банкнотний папір, тактильна дискримінація, лакування, вододисперсний лак, наносрібло, забруднення банкнот, тактильні відмінності, тактильні властивості банкнот.

Постановка проблеми та аналіз попередніх досліджень

Лакування банкнот $€$ дієвим методом підвищення зносостійкості банкнот (особливо стійкості до загального забруднення). Фахівці оцінюють вагомість такого фактору, як лакування, серед інших напрямків підвищення зносостійкості банкнот, у 35 \% [1]. Нанесення спеціальних лаків на банкнотний папір дозволяє збільшити стійкість до забруднення більше ніж на 50 \%, збільшуючи термін служби банкнот майже в 2 рази [2].

Актуальне питання для виробників банкнот протягом останніх років - розробка технологій поліграфічного виробництва, метою яких $є$ якнайдовше збереження їх чистими з точки зору бактеріального забруднення [3-5]. Можливим варіантом вирішення даного питання $€$ створення захисного антибактеріального покриття на банкнотах шляхом лакування їх поверхні вододисперсним лаком 3 додаванням колоїдного розчину нанорозмірних часток срібла для зниження рівня мікробіологічного забруднення банкнот в обігу [6]. При цьому важливою умовою $€$ незмінність тактильних відчуттів у користувачів банкнот.

Банкноти української гривні мають певні тактильні характеристики, що обумовлене, як шорсткістю основи банкноти, наявністю водяних знаків, так і присутністю елементів, створених за допомогою металографічного (інтагліо) друку. Утворений захисний шар лаку не повинен спотворювати тактильних відчуттів від банкнот, котрі $€$ усталеною ознакою автентичності для населення. Важливість незмінності тактильних відчуттів зумовлена тим, що у такому

(c) $2014 \mathrm{p}$. 
випадку поряд із покращенням споживчих властивостей та підвищенням безпечності банкноти буде відсутня необхідність проведення широкомасштабної високовартісної інформаційнороз'яснювальної роботи серед населення, пов'язаної зі змінами в питанні, яке без зазначеної роботи здатне було б викликати у суспільстві нерозуміння та сумніви в автентичності лакованих банкнот.

У фаховій літературі описана методика тактильної дискримінації паперу, що базується на 3-альтернативній процедурі відбору «одного 3 ...». Для дослідження залучаються незалежні експерти, які оцінюють зразки. При цьому вони діляться на групи, що складаються 3 двох чоловік - дослідника та реєстратора. 3 метою забезпечення доступності виключно тактильних відчуттів у тестуванні застосовують зорове та слухове маскування 3 використанням білого шуму через навушники та непрозорі окуляри.

Експериментатор формує групи зразків, кожна з якої має по три варіації зразків, причому два зразка із варіацій є представниками одного типу, а третій - іншого типу. Експериментатор поміщає потрібну групу зразків у необхідній послідовності. Дослідник повинен почергово дослідити зразки, взявши один зразок однією рукою, перекласти в іншу та повернути на місце. Час контакту з кожним зразком - 1-2 секунди; пряме порівняння двох зразків одночасно виключається. В результаті дослідник має визначити той екземпляр, який за його відчуттями не є схожим на два інших, тобто відібрати «один із...». Реєстратор нотує результати дослідження та передає на обробку експериментатору [7].

\section{Мета роботи}

Метою даного дослідження було удосконалення описаної в літературі методики тактильної дискримінації паперу для уможливлення використання її у рамках дослідження тактильних властивостей лакованих банкнот, а також проведення експериментального дослідження тактильних властивостей банкнот після лакування вододисперсним лаком із додаванням концентрату нанорозмірних часток срібла у якості бактерицидного агенту.

\section{Результати проведених досліджень}

Опис зразків

Досліджуваними зразками є лаковані паперові банкноти номіналом в 2 гривні, розділені на 9 груп відповідно до концентрації складових у об'ємі суміші для лакування [8]:

- воднодисперсний лак у чистому вигляді;

- концентрат нанорозмірного срібла;

- дистильована вода (для регулювання в'язкості суміші).

Банкноти, що підлягали лакуванню, порівнювалися з новими банкнотами, відібраними із того ж тиражу, що і зразки із захисним покриттям.

Опис експериментальних зразків наведено у табл. 1.

Суб'єкти дослідження

Суб'єктивна оцінка зразків банкнот була проведена вісім- 
Таблиця 1

Опис досліджуваних зразків із захисним покриттям

\begin{tabular}{|c|c|c|c|c|}
\hline \multirow{2}{*}{$\begin{array}{c}\text { № } \\
\text { групи }\end{array}$} & $\begin{array}{c}\text { Позначення } \\
\text { зразків }\end{array}$ & \multicolumn{3}{|c|}{$\begin{array}{c}\text { Концентрація складових суміші для лакування } \\
\text { (вміст речовини в об'ємі суміші) }\end{array}$} \\
\cline { 3 - 5 } & & чистого лаку, \% & $\begin{array}{c}\text { концентрат } \\
\text { нанорозмірного срібла, } \\
\%\end{array}$ & дистильованої води, \% \\
\hline 1 & $1.1-1.5$ & 98,0 & 2,0 & 0,0 \\
\hline 2 & $2.1-2.5$ & 88,2 & 1,8 & 10,0 \\
\hline 3 & $3.1-3.5$ & 78,4 & 1,6 & 20,0 \\
\hline 4 & $4.1-4.5$ & 95,0 & 5,0 & 0,0 \\
\hline 5 & $5.1-5.5$ & 85,5 & 4,5 & 10,0 \\
\hline 6 & $6.1-6.5$ & 76,0 & 4,0 & 20,0 \\
\hline 7 & $7.1-7.5$ & 90,0 & 10,0 & 0,0 \\
\hline 8 & $8.1-8.5$ & 81,0 & 9,0 & 10,0 \\
\hline 9 & $9.1-9.5$ & 72,0 & 8,0 & 20,0 \\
\hline
\end{tabular}

надцятьма незацікавленими волонтерами: студентами віком від 18 до 22 років чоловічої та жіночої статі. Згідно з рекомендаціями, було залучено одну ліворуку людину (шульгу).

\section{Методика дослідження}

1. Підготовчий етап

18 суб'єктів, які оцінюють зразки, було поділено на 9 груп відповідно до кількості рецептур суміші для лакування (табл. 1), кожна $з$ яких складалася 3 двох чоловік - дослідника та реєстратора.

Дев'ять груп банкнот містили у собі по 5 лакованих зразків (лаковані банкноти X.Y, де $X$ - номер групи лакованих банкнот, $X=\overline{1 ; 9} ; Y-$ порядковий номер банкноти в межах групи, $Y=\overline{1 ; 5}$ ), кожен 3 яких порівнювався $з$ двома новими банкнотами без захисного покриття (нові нелаковані банкноти «N») (табл. 2).

Для зведення до мінімуму впливу стану шкіри на результати експерименту учасники ретельно вимили та висушили руки перед початком тестування. Для уникнення впливу зовнішніх факторів на характеристики банкнот (так як паперова основа банкнот $\epsilon$ гідрофільною) та на зміни стану шкіри (щоб уникнути зайвого потовиділення) було встановлено температуру повітря на рівні $22{ }^{\circ} \mathrm{C}$ та відносну вологість $26 \%$.

3 метою забезпечення доступності виключно тактильних відчуттів у тестуванні було застосоване зорове та слухове маскування за допомогою використання непрозорих окулярів та білого шуму через навушники [7].

2. Проведення тестування

Кожна пара учасників отримала по одній групі зразків у необхідній послідовності. Так, 5 банкнот першої групи (табл. 1) були досліджені першою групою експертів, 5 банкнот другої групи - другою і т. д.

Учасникам-дослідникам було доручено почергово взяти екземпляр однією рукою, перекласти в іншу руку та обома руками намагатися якомога 


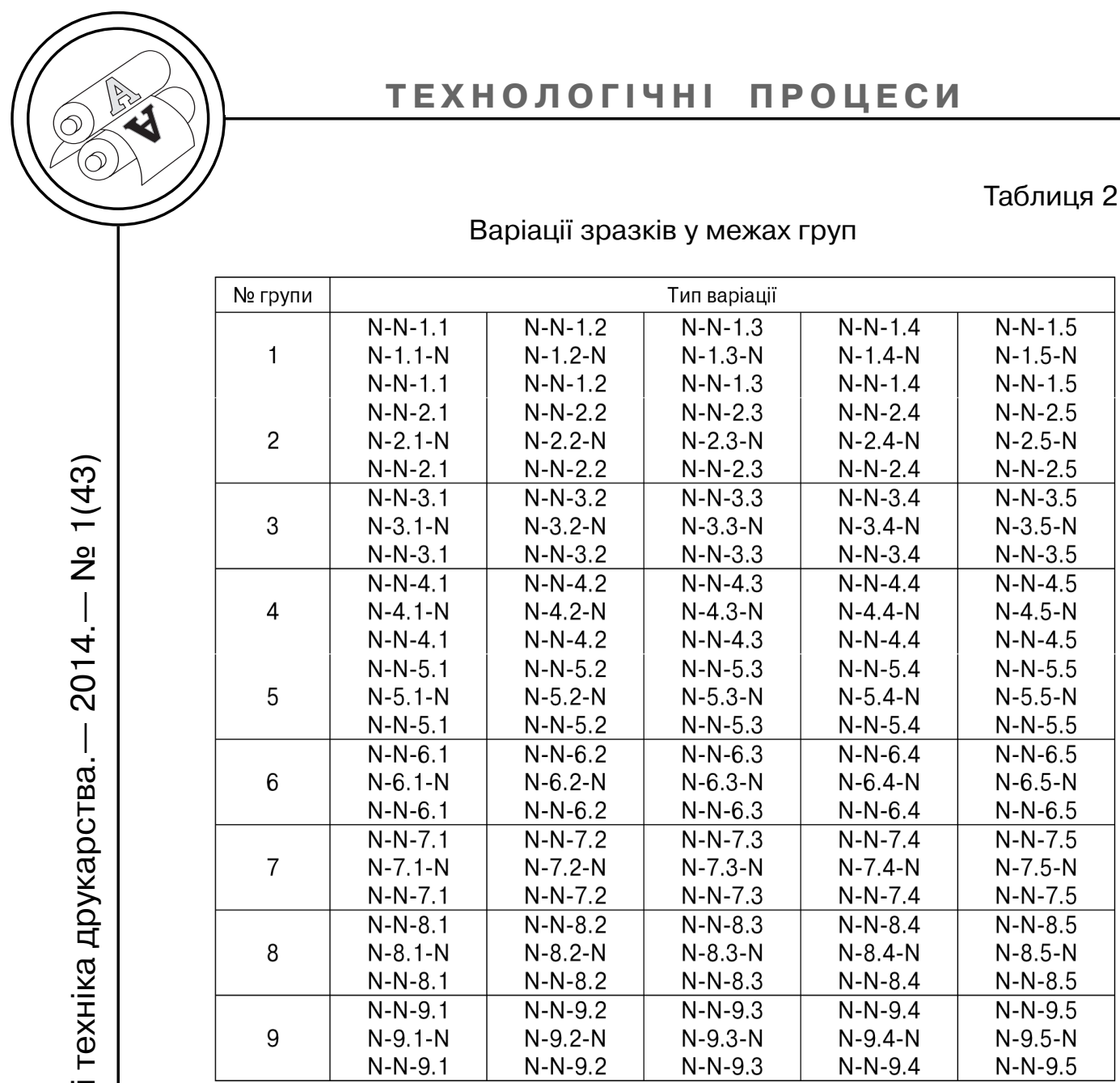

точніше визначити відносний рівень шорсткості поверхні банкноти. Після цього дослідником усно реєструвався зразок, який за його відчуттями не був схожим на два інші зразки, тобто відбирався «один із...». Відмінний, на думку дослідника, зразок реєстратором було позначено «1», інші два - 0 ». У разі, якщо дослідник був не в змозі ідентифікувати відмінний зразок, всім трьом екземплярам у підгрупі присвоювалась оцінка «0» для виключення ймовірності випадкових оцінок. Дані занесено до таблиці 3.

Для процедури тактильного оцінювання зразків було відве- дено 5 секунд, при цьому пряме порівняння між двома зразками одночасно не дозволялося.

Після тестування експериментатором були зібрані дані з усіх груп учасників.

\section{Обробка результатів}

Утворене лакове покриття на поверхні банкнот повинне бути мінімально відчутним на дотик. Тому експеримент із тактильної дискримінації можна вважати успішним, якщо для кожної варіації X.Y=0, тобто у разі, коли лаковані банкноти не були ідентифіковані дослідником серед трьох поданих йому зразків. При цьому вірогідно, що група, лаковані банкноти якої були дис- 
Результати тактильної дискримінації зразків

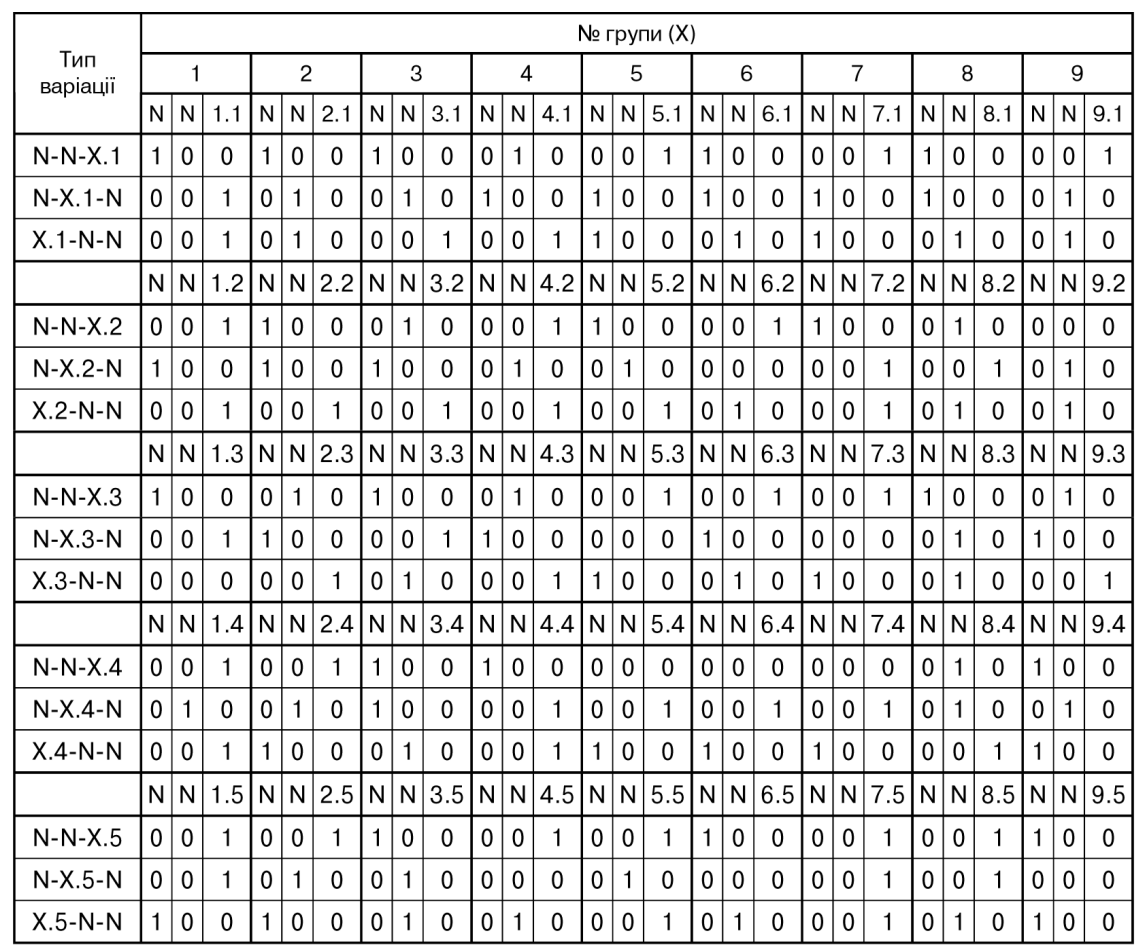

Примітка: Якщо дослідник дискримінує один із зразків $\mathrm{N}$-типу, то оцінка «1» у даній варіації ставиться у будь-якому стовпчику.

криміновані найменше число разів, має оптимальну рецептуру суміші для лакування, оскільки створене нею покриття найменш відчутне на дотик.

Якщо ж $X . Y \neq 0$, тобто дискримінувався зразок серед $\mathrm{N}$, то експериментатором з'ясовуються причини такої дискримінації.

За даними таблиці 3 було визначено кількість та відсоток дискримінованих лакованих банкнот 3 п'ятнадцяти можливих. Чим менше значення тактильної дискримінації у відсотках для групи, тим кращим вважається результат. Результати занесені до таблиці 4.

За результатами табл. 4 було побудовано діаграму (рис. 1), з якої видно, що оптимальні результати тактильної дискримінації отримали банкноти 9 групи (дискриміновані в $13 \%$ випадків), задовільні результати - банкноти 3 та 6 груп (по $20 \%$ ), а також 2 та 8 груп (по $27 \%$ ). Найгірші результати у банкнот 1 групи (60 \%).

У результаті експерименту виявлено, що різні рецептури суміші для лакування можуть порізному впливати на тактильні відчуття у користувачів банкнот. Так, встановлено залежність, що чим більший вміст лаку (сухого залишку) у рецептурі суміші, тим вірогідніше виявлення тактильних відмінностей у лакованих банкнот (рис. 2). 


\begin{tabular}{l} 
Обробка результатів \\
Таблиця 4 \\
\hline \\
\cline { 3 - 8 }
\end{tabular}

3 рисунку 2 видно, що найменше число разів були дискриміновані банкноти 9 групи 3 вмістом чистого лаку $72 \%$ у об'ємі суміші, а також банкноти 3 та 6 групи - 78,4\% та $76 \%$ відповідно. Таким чином, виявлено залежність, що із зменшенням вмісту лаку (i, відповідно, збільшенням кількості концентрату нанорозмірних часток срібла та води) у об'ємі суміші для лакування зменшуються тактильні відмінності поверхонь лакованих та нелакованих зразків.

\section{Висновки}

У дослідженні за допомогою методики, що базується на 3-альтернативній процедурі відбору «одного з ...» було проведено тактильну дискримінацію поверхні банкнот, лакованих вододисперсним лаком із додаванням бактерицидного агенту (нанорозмірних часток срібла).

Було удосконалено описану в літературі методику тактильної дискримінації паперу для уможливлення використання їі у рамках дослідження

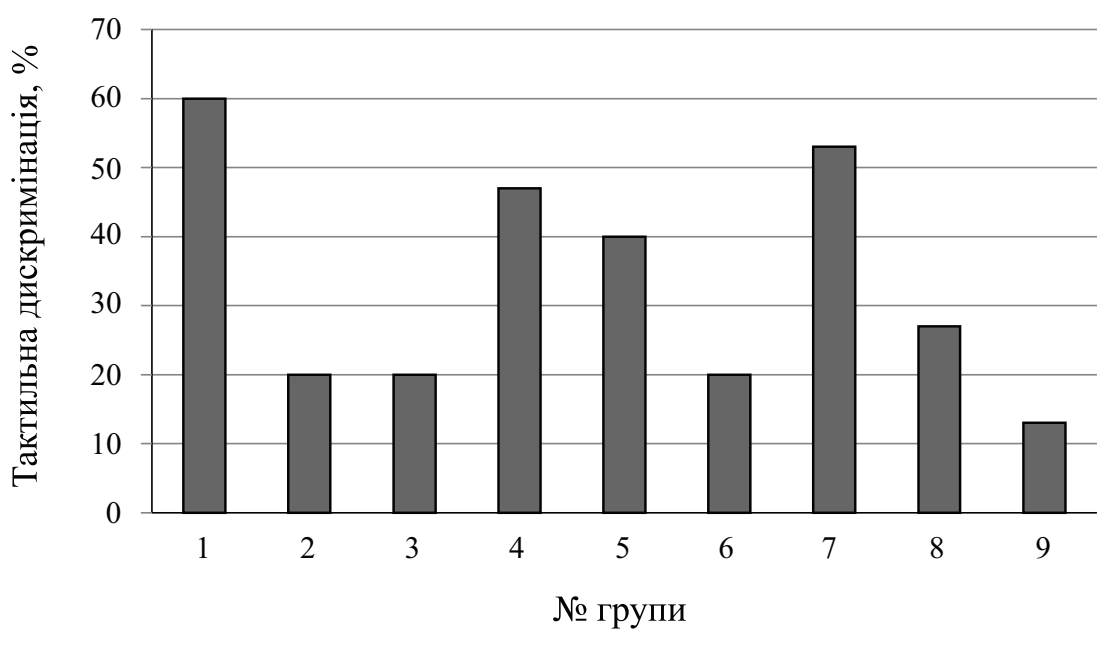

Рис. 1. Результати тактильної дискримінації 


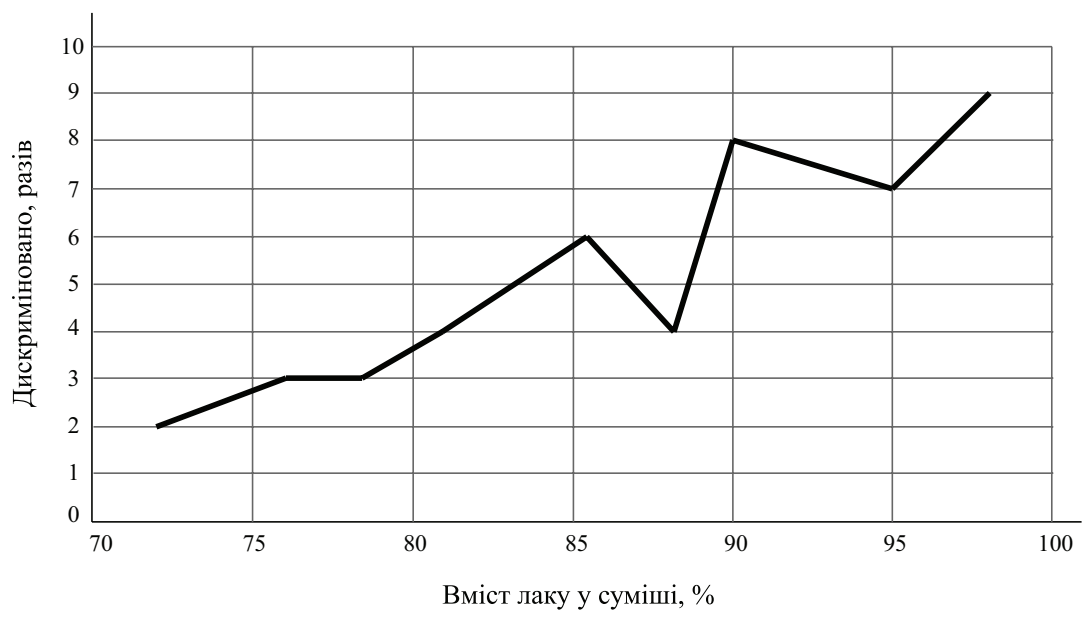

Рис. 2. Залежність тактильних відмінностей поверхні зразків від рецептури суміші для лакування

тактильних властивостей лакованих банкнот - збільшено час контакту з досліджуваним зразком, надано можливість оцінки зразка двома руками одночасно. Крім того, на відміну від запропонованого методу [7], експертам, які не могли дискримінувати один зразок із трьох, дозволялося присвоювати їм однакові оцінки («0»).

Результати опитування залучених експертів дають підстави стверджувати, що рецептура суміші для лакування може викликати зміни звичних тактиль- них відчуттів у користувачів банкнот. Виявлено залежність, що із зменшенням вмісту лаку у об'ємі суміші для лакування зменшуються тактильні відмінності поверхонь лакованих та нелакованих зразків. Оптимальним складом суміші для лакування була визначена рецептура 9 групи банкнот.

$$
\text { Отримані результати }
$$
доцільно врахувати для організації досліджень з розробки технології виготовлення банкнот підвищеної безпечності для людини.

\section{Список використаної літератури}

1. H. A. M. de Heij. Durable banknote paper. - De Nederlandsche Bank N. V., Amsterdam, Netherlands. - March, 1995. - P. 1-11. - De Nederlandsche Bank NV. - Шлях доступу : http://www.dnb.nl/binaries.

2. Не просто бумага // Водяной знак. - январь-февраль 2008. № 1-2(57-58).

3. Basavarajappa K. Study of bacterial, fungal, and parasitic contaminaiton of currency notes in circulation / K. Basavarajappa, P. Rao, K. Suresh // Indian Journal of Pathology \& Microbiology. - 2005. - V. 48(2). - P. 278-279.

4. Kofi Aidoo. Dirty money / Kofi Aidoo // Microbiology Today. - 2011. P. $162-165$.

5. Pope T. W. Bacterial Contamination of Paper Currency / T. W. Pope, P. T. Ender, W. Woelk K., M. A. Koroscil // Southern Medical Journal. - 2002. V. $1 .-$ P. $21-25$. 
6. Антибактеріальний папір з наночастинками срібла [Текст] / Китай. CN202273145. ? 13.06.2012.

7. Summers I. R. Tactile discrimination of paper / I. R. Summers, R. J. Irwin // Biomedical Physics Group.

8. «Концентрат коллоидного раствора наноразмерных частиц серебра «АgБион-2»; рецептура; технологический регламент; инструкция по применению средства : ТУ 9392-003-44471019-2006. - [Чинний від 31.07.2009]. - М. : АНО Институт нанотехнологий МФК, 2009. - 6 с.

\section{References}

1. H. A. M. de Heij. Durable banknote paper. - De Nederlandsche Bank N. V., Amsterdam, Netherlands. - March, 1995. - P. 1-11. - De Nederlandsche Bank NV. - Shliakh dostupu : http://www.dnb.nl/binaries.

2. Ne prosto bumaga // Vodjanoj znak. - janvar'-fevral' 2008. № 1-2(57-58).

3. Basavarajappa K. Study of bacterial, fungal, and parasitic contaminaiton of currency notes in circulation / K. Basavarajappa, P. Rao, K. Suresh // Indian Journal of Pathology \& Microbiology. - 2005. - V. 48(2). - P. 278-279.

4. Kofi Aidoo. Dirty money / Kofi Aidoo // Microbiology Today. - 2011. P. $162-165$.

5. Pope T. W. Bacterial Contamination of Paper Currency / T. W. Pope, P. T. Ender, W. Woelk K., M. A. Koroscil // Southern Medical Journal. - 2002. V. 1. - P. 21-25.

6. Antybakterialnyi papir z nanochastynkamy sribla [Tekst] / Kytai. CN202273145. ? 13.06.2012.

7. Summers I. R. Tactile discrimination of paper / I. R. Summers, R. J. Irwin // Biomedical Physics Group.

8. «Koncentrat kolloidnogo rastvora nanorazmernyh chastic serebra «AgBion-2»; receptura; tehnologicheskij reglament; instrukcija po primeneniju sredstva : TU 9392-003-44471019-2006. - [Chynnyi vid 31.07.2009]. - M. : ANO Institut nanotehnologij MFK, 2009. - $6 \mathrm{~s}$.

\section{Проведено исследование тактильных свойств бумажных банкнот после лакирования вододисперсным лаком с использованием 3-альтернативной процедуры отбора «од- ного с трёх».}

Ключевые слова: банкноты, банкнотная бумага, тактильная дискриминация, лакирование, вододисперсный лак, наносеребро, загрязнение банкнот, тактильные различия, тактильные свойства банкнот.

The article is dedicated to the investigation of tactile discrimination of paper banknotes according to the 3-alternative forcedchoice procedure.

Keywords: banknotes, banknote paper, tactile discrimination, varnishing, water-based varnish, nanosilver, contamination of banknotes, tactile differences, tactile properties of banknotes. доцент, НТУУ «КП।» 